\title{
A PATHWAY OF DIGITAL LEARNING IN CHANGING PARADIGM: THE CONTEXT OF COVID-19
}

\author{
Prashant Kumar \\ Assistant Professor (Business Administration). Government Lohia College, Churu (Raj.) India \\ Email: pkumar26r@gmail.com
}

\begin{abstract}
The COVID-19 virus has trapped the entire world under the lockdown situation. The impact of this global pandemic on education is very crucial. The COVID-19 pandemic has altered the teaching calendar and teaching-learning assignments. The Ministry of Human Resource Development, Government of India is closely monitoring the COVID-19 effects on education and assessing future workforce requirements. This write-up reveals many dimensions of Digital Learning in respect of changing paradigm of education due to COVID-19. This paper is based on secondary sources supported by various Indian Government organizations. The main objective of this paper is to create digital awareness among students, parents and academic fraternity about digital pedagogy, pedagogical innovations and digital initiatives by the Ministry of Human Resource Development (MHRD). Everyone can be benefitted from this paper by acquiring the necessary information about digital educational practices in India.
\end{abstract}

Key words: COVID-19, Learning Management System (LMS), Pedagogical Innovations.

\section{Introduction}

Today, India is on a war footing and heading towards socio-economic crisis as well as education reforms due to COVID 19. This has brought new challenges and new opportunities for the entire world. As we all know that India has made significant socio-economic growth in the last few years. In this regime, we need high quality and techno-friendly human resources for sustainable education experience and environment. Unfortunately, the existing traditional education system is not much able to face the challenges in this COVID-19 context. The aim of this paper is to analyze the relevance of pedagogical innovations and e-learning strategies in today's context. The major focus is on quality education and adequate recognition. In this regime, India has no choice except to compete and perform in a globalized economy. To play a constructive role in creating an educational environment and knowledge-based society, we have online educational platforms. The online or ICT based education will encourage the teachers as well as students of educational institutions to adopt innovative virtual classroom teaching methods ( $P$ Jah, 2005). This will boost teachers to exchange their knowledge and innovation in learning with their colleagues within and outside the institution. "A teacher had commitment and involvement to work for the cause of universalization of education and imparting quality education, nothing could be turned substantially. Any scheme that is adopted must be concretized. It would do well if every teacher takes a vow to do his might to make educational schemes envisaged by the effort of India, a successful one."

\section{Objectives}

The CORONA driven forces due to COVID-19 have presented immense challenges in front of us. This paper will focus on the following issues:

- Identifying and analyzing the significance of online education.

- Analysing the dynamics of education and formulating new designs.

- Promoting connection among academicians, students, professionals. 
- Understanding students' response to educational innovative reforms.

- Inculcating values in this hazardous time.

- Developing and encouraging the advanced pedagogical innovations.

\section{Methodology}

The nature of this paper is descriptive and it is based on various reports, policy papers, handbooks, journals, e-books of MHRD, Government of India, UGC, AICTE and other eminent institutions of India. The analysis in this paper is presented through the information available on various websites of educational institutions under MHRD, Government of India. It is hoped that stakeholders concerned would find the consolidated paper useful in this pandemic situation.

\section{Pedagogical Innovations}

Pedagogical innovation is a new way of teaching contrasting with traditional teaching methods. It is concerned with new and unique ideas. In this regard, Digital pedagogy enhances learning opportunity for authentic assessment. The following examples of pedagogical innovations will provide a better understanding:

\section{Examples:}

(a) Tablets, laptops and mobile devices in form of e-books, e-contents

(b) Flipped Classrooms- SWAYAM, Learning Management System-LMS, Moodle and Blackboard

(c) Personal Learning Network- Twitter, Blogging and other Social Media platforms

(d) Smart Class Room

The following collaborative and communicative tools are being used in the shape of pedagogical innovations:

${ }^{*}$ SKYPE- www.skype.com

${ }^{*}$ G-suite (Google Drive, Google Forms, Google Maps, Hangouts)

*Discussion Forum, Poll Everywhere, Podcasting and Webcasting, PADLET, WIKIS

\section{E- Learning}

India has great potential to empower and transform itself into a globalised knowledge economy. In this regime a large pool of educational fraternity should further open knowledge space for Indian citizens. We are living in information- knowledge driven world, expecting a new set of skills. The term E-learning is technology based tool to facilitate learning environment which covers (a) Computer Based Learning (b) Web Based Learning (c) Virtual Classroom (d) Digital Collaboration. E-learning provides interactive learning experience, access to online tutors. The participants can be trained to develop an ability to discuss the matter with others. Teacher educator uses many features like; interaction in between the pupil teacher, text messages and emails from learning management system. In Web based system, teacher educator provides online assignment, access with classroom sessions, performance management and live lectures. Online assignments offered by a teacher educator with authenticate personal interface provides collaborative learning (Saluja, 2007). Learner can download, complete and submit the assignments online. The system tracks every assignment and progress of individual learner. Application of $E$ technologies in the area of education provides global knowledge society and life long learning. India is one of the affected countries with CORONA disease. To safeguard the present and future generations there is a strong need to develop online education system. Teachers should extend the supportive system to the student community in the form of information, positive attitude and development of technical advancement for sustainable development. At present, the time has come to bring education directly at home. In this regime, $\mathrm{E}$ learning is necessary to this goal. $\mathrm{E}$ learning is very important as the nation faces the challenge of big disaster and to provide education to millions of learners. In the words of Peter Drucker "Online education is creating a new and distinct educational realm. There is 
a global market that is potentially worth hundreds of billion of dollars." Today, there have been significant attempts in this direction by UGC, MHRD, DST and CSIR.

\section{Video Program of IGNOU}

The Indira Gandhi National Open University (IGNOU) is providing online educational resources through e- gyankosh, GYAN DARSHAN, an exclusive educational TV channel funded by Ministry of Human Resource Development (MHRD). Live educational programmes are available on www.ignouonline.ac.in . India has a vast opportunity in this direction. Open learning resources are playing prominent role in this regard. E learning is gaining popularity in academic and training world for providing learner centric and quality education with inexpensive solutions. Teachers must care about the process and must be willing to devote time to explore new horizons. In other words, they must think how a particular strategy is useful.

\section{Moodle}

Moodle is an Online Learning Management System covering educators to make their self website having courses. It gives specific features like course homepage, discussion forums, and content sharing avenues. It gives a single robust, secure and integrated system for personalized and blended learning.It facilitates teaching learning process in shape of online teaching materials.

\section{M-Learning}

The use of mobile technology in education can be defined as "mobile education" or "Meducation".M- education provides opportunity to deliver educational materials efficiently in learner educator interaction. Educational contents can be provided to students through mobile technology. Students can interact with peers and educators in real time. Mobile education gives flexibility to student when the need arises, no matter where they are. It provides anytime and anywhere and anybody learning or education (Karan, 2003). Major applications of mobile phones like message service (SMS-Text and Picture Messages), Organiser-Diary and Alarm, Calculator, currency converter, temperature converter has great educational importance in practical sessions. Similarly Radio, Video, TV, Voice Call, Print avenues of mobile phones can be utilised in teaching learning process. Nowadays, the news papers are coming in e-paper under print media. Many facilities are available like Browsing, downloading, GPRS, sending and receiving emails, blogging, shareware, freeware through internet. Besides, stock market information, astrology, travel, entertainment, sports, finance and results can be accessed. Through mobile teaching, we can prepare the students for the real world.

\section{Lead and Rebuild India through ICT}

In the words of Padamshree Vijay P. Bhatkar " A new paradigm in education is emerging. This paradigm will have transformational impact on our Universities. This century belongs to ICT and our young generation is going to build India as number one nation of the world." In 1980, Vikram Sarabhai provided the Satellite Institutional Television Experiment and launched Television oriented education to Indian farmers. Today, it is a time of Education -To-Home through ICT. India has performed well in ICT and now the challenge is to use this digital technology for enhancing and sustaning our traditional education system. It is necessary that not only government but all of us should recognise the growing demand of online education. Furthermore, several problems are faced by the teacher's and learners in the use of ICT like content quality, connectivity issues and lack of stuctured learning environment. But, we can't stop learning. Our planning and execution should be according to practical aspects. In this regime, India has huge opportunity in online education.(University News, October,2007)

\section{Digital/ICT Initiatives in India}

With this COVID-19 crisis, educational institutions have suspended campus learning. In the wake of institute lockdown because of COVID-19 outbreak, many educational institutes have shifted to 
online mode for ensuring quality education in the country. In India, there are many ICT initiatives of MHRD, UGC, Information and Library Network (INFLIBNET) and Consortium for Educational Communication (CEC) in the shape of online digital platforms. The following collaborative learning platforms are presented in such a manner:

\section{SWAYAM}

SWAYAM (Study Webs of Active Learning for Aspiring Minds) is an online education platform having online courses in school education (28 course modules in 12 subject areas Developed by NCERT), graduation and post graduation to be used by anyone, anywhere and anytime. All courses are prepared by academic fraternity of India and are available free of cost to any learner. The courses available on SWAYAM provides: (1) Video Lectures (2) Reading material (3) Self Assesment Test (4) Discussion Forum.

\section{SWAYAM PRABHA}

For acquiring new skills at home, SWAYAM PRABHA provides 32 channels telecasting quality school and higher education contents $24 \times 7$. Through channel 'Kishore Manch' students can have access of e contents approved by NCERT on a $24 \times 7$ for classes of X-XII in various subjects.It provides high quality curriculum based e-contents in various disciplines such as arts, science, commerce, humanities and social sciences, agriculture, medicine, law and engineering.

\section{e-PG Pathshala}

It is funded under NME-ICT and being executed through University Grants Commission. It is an easily accessible online gateway to all post graduate courses. It covers high quality; curriculum based e-content modules (Text and Video) in Post Graduate disciplines of social sciences, arts, fine arts, humanities, natural and mathematical sciences.

\section{UG and PG MOOC}

It is a vertical of SWAYAM and a source of good quality learning material of the SWAYAM (Nontechnical) archived courses.

\section{DIKSHA}

The DIKSHA (Digital Infrastructure for Knowledge Sharing) is a digital platform having learning material of school education for teachers, students and parents.

\section{NPTEL}

The NPTEL (National Programme on Technology Enhanced Learning) provides online learning in science and engineering with no pre-qualification and no age limit.

\section{Consortium for Educational Communication (CEC)}

It is an inter university centre of University Grants Commission (UGC). Today, 18 media centers are facilitating educational knowledge dissemination.It covers e- content in 87 undergraduate courses having 24110 modules.

\section{Shodhganga}

It is a open access repository platform of Indian Electronic Dissertations for researchers to deposit their Ph.D theses and make it available to academic fraternity as well as scholarly community.

\section{NISHTHA}

The NISHTHA (National Initiative for School Heads and Teachers Holistic Advancement) is an integrated teacher training digital platform for teachers of DIETs, DLEd. Institute having access of various course modules, videos, audios and other educational material. 


\section{VIDWAN}

It is a database of experts. It provides information about experts to peers, collaborators, policy makers and funding agencies.

\section{NROER}

The National Repository of Open Educational Resources (NROER) is a digital platform of good quality informational content on various subjects in various languages.

\section{National Digital Library}

The National Digital Library is a repository of academic contents in various formats. It stores books, articles, videos, audios, thesis and other educational materials with single window search system. It provides interface for leading Indian languages for all academic levels.

\section{e-Shodh Sindhu}

It provides access to e-resources to universities, colleges and centrally funded technical institutions in India. It is being executed by INFLIBNET centre. It is an archival access of peer reviewed journals and bibliographic, citation databases in various disciplines from a large number of publishers under NME-ICT.

\section{Conclusion}

It is to ensure social distancing as prevention of spread of COVID-19. To combat and ensure uninterrupted teaching and learning at home and minimize academic loss, the UGC has directed to academicians to make productive use of time in this critical period. In this regard, the Ministry of Human Resource Development has initiated "Bharat Padhe Online" campaign. (UGC letter no. F No. 1-4/2020(CM) dated 11 April 2020). In this time, the selection of teaching modules and videos, preparation of a roadmap for admissions, declaration of results and conduction of examination with proper timelines is also a very important aspect. In this situation, the role of teachers has emerged as a COVID 19 warrior for preventive and precautionary measures. The working style has been changed in a manner like work from home. The Education Department of Himachal Pradesh is preparing e-learning program for students of Class X and XII in the shape of study material for telecasting on Himachal Pradesh Doordarshan. As per feedback received from various sources, many students are not having smartphones and computers for accessing educational content. Recently, it has been decided to telecast "Har Ghar Pathshala" by Department of Higher Education, Himachal Pradesh. In this regard, we should use; Effective use of college and university website for providing latest and relevant information to the learners; Sensitize the learners about media services, focused course delivery for quality education. In recent times, with technological developments, the learners of today's prefer electronic book(e-books), visit and watch webinars, live videos on webcast or through YouTube, chatting and video conferencing with each other. But, with proper planning and training, infrastructure development it can be easy. In this way, the role of teachers, teaching institutions has been transformed. It is high time that academic fraternity should come together for challenges along with quality education through digital platforms.

\section{References}

1. Most, S.L. \& Holschuh, J. (2000). Active learning strategies for college success. Boston: Alyn\&Bacon

2. Jah $\mathrm{P}$ K (2005). Online Pedagogy, Interactive Teaching Learning Strategies, Vista International Publishing House, New Delhi

3. Verma Romesh (2007). Education -Open Learning in Global Society,'E learning Environment, Anmol Publication, New Delhi

4. Singh, Karan, (2003). "Education for youth in the Global Society", Yojana, September.

5. V. Parikh and D. Saluja (2007). Higher Education, State and State, University News, 45(19), May 
6. Arockiayasamy, S. (2005). Video conferencing through Internet (Tamil) Daily Thanthi, September, 2005

7. Yoong kai Seng. (2003). Using the internet the easy way. Malaysia: Minerva Publication.

8. Toffler, A.1990. Future Shock, New York: Bantam Books

9. Toffler, A.1990. Power Shift. New York: Bantam Books

10. Jayant Vyas (2001). Professionalization of Teacher Education, University News, 39(6), Feb.5.

11. www.evaluserve.com

12. www.ignou.ac.in

13. www.education.nic.in

14. www.ncert.nic.in

15. www.ncte-in.org

16. www.hte.rajasthan.gov.in

17. www.ugc.ac.in

18. https://ess.inflibnet.ac.in

19. https://diksha.gov.in

20. https://nroer.gov.in

21. https://nishtha.ncert.gov.in

22. https://ndl.iitkgp.ac.in

23. https://shodhganga.inflibnet.ac.in

24. www.ignouonline.ac.in

25. https://swayam.gov.in

26. https://swayamprabha.gov.in

27. https://egpg.inflibnet.ac.in

28. https://cec.nic.in

29. https://YouTube.com/user/cecedusat

30. www.mhrd.gov.in 